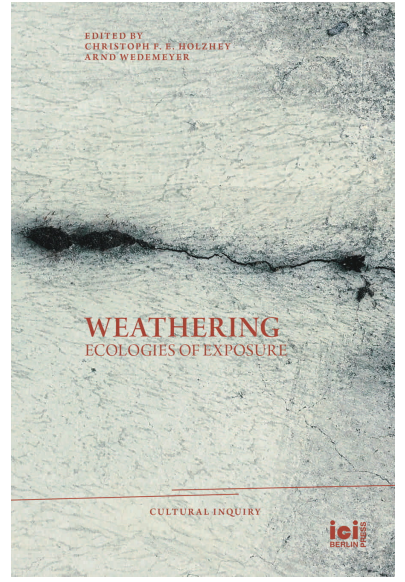

Weathering: Ecologies of Exposure, ed. by Christoph F. E. Holzhey and Arnd Wedemeyer, Cultural Inquiry, 17 (Berlin: ICI Berlin Press, 2020), pp. 295-309
DELFINA CABRERA (i)

\section{Confined Weathers}

Graciela Iturbide and Mario Bellatin's The Bathroom of Frida Kahlo/Demerol without Expiration Date

\author{
CITE AS:
}

Delfina Cabrera, 'Confined Weathers: Graciela Iturbide and Mario Bellatin's The Bathroom of Frida Kahlo/Demerol without Expiration Date', in Weathering: Ecologies of Exposure, ed. by Christoph F. E. Holzhey and Arnd Wedemeyer, Cultural Inquiry, 17 (Berlin: ICI Berlin Press, 2020), pp. 295-309 <https://doi.org/10.37050/ci17 15>

\section{RIGHTS STATEMENT:}

(C) by the author

Except for images or otherwise noted, this work is licensed under a Creative Commons Attribution-ShareAlike 4.0 International License.

ABSTRACT: What is the effect of weathering in a confined space? What if this space is the bathroom of the famous Mexican painter Frida Kahlo? Writer Mario Bellatin and photographer Graciela Iturbide venture into this once intimate room and through a series of artistic interventions breathe new life into it. The logic of the archive is their guiding principle: in order to preserve what has been locked away and stored, it must be exposed and put to new uses. 


\section{Confined Weathers}

Graciela Iturbide and Mario Bellatin's The Bathroom of Frida Kahlo/Demerol without Expiration Date

DELFINA CABRERA

\section{WEATHERING AT WORK}

The images evoked by the word 'weathering' rarely refer to interiors. ${ }^{1}$ They are often accompanied by the belief that weathering must be fought, stopped, or controlled. But perhaps the only successful battles against this pervasive enemy are those that join forces with it. Many artists have understood this and rather than avoiding the supposed evils of weathering, they have copied them, turning the work of unseen powers and the feared passage of time into creative devices. Weathering, in this sense, is at the very heart of art. It dwells inside the work, in its most sheltered intimacy.

When in 1954 the Mexican painter Diego Rivera decreed that Frida Kahlo's bathroom should remain locked for fifteen years after his death, he could not foresee that this period would stretch into almost five decades. In 1958, the house where they had lived was turned into

1 I am grateful to Claudia Peppel, Marlon Miguel, Christoph Holzhey, Arnd Wedemeyer, and Graciela Goldchluk for their generous readings and insightful comments on this essay. 
a museum, but the bathroom was made accessible to the public only in 2005 when the museum invited photographer Graciela Iturbide and writer Mario Bellatin to engage with it. Their excursions resulted in a double-sided book that read The Bathroom of Frida Kahlo, when turned in one direction, and Demerol Without Expiration Date, when turned in the other. The first title corresponds to a series of photographs by Iturbide and the second to a text by Bellatin. ${ }^{2}$ Both, the photographs and the text, address the work of weathering on one of the most iconic artistic legacies of the twentieth century.

This book, at first touch, entails an altering gesture, a certain disorder: from the first bourgeois fortress of privacy, the ultimate architectural element, the bathroom, Iturbide and Bellatin extract and expose objects that had been concealed. Frida's dried corsets, the rusted enema pots, a box of Demerol painkillers, a poster of Stalin warped by humidity, an anatomy chart of intra-uterine life (intact), the metal crutches, the stained hospital gown, an orthopaedic leg leaned against the wall, two stuffed birds, and a turtle are some of those things, now part of the museum's permanent collection and protected under strict conservation rules. But The Bathroom of Frida Kahlo/Demerol without Expiration Date offers to the eye what the display cases cannot show. Within Iturbide and Bellatin's book, Kahlo's ambivalent presence bears witness to this effort and opens up questions about how art, improper bodies, and medicalization mingle, but also the relations between art, the process of weathering, and the art market. ${ }^{3}$

After her death, Frida Kahlo was captured in a continuous present. She became an international celebrity, a trademark - licensed by the Frida Kahlo Corporation - and since 2010, her portrait can be found on billions of five hundred Mexican peso banknotes. ${ }^{4}$ Likewise,

2 Graciela Iturbide and Mario Bellatin, El baño de Frida Kahlo/Demerol, sin fecha de caducidad (Ciudad de México: Galería López Quiroga/Editorial RM, 2008).

3 For a pioneering analysis of Iturbide and Bellatin's book, see Paola Cortés-Rocca, 'La insoportable levedad del yo. Iturbide y Bellati en El Baño de Frida Kahlo', Filología, 44.1 (2012), pp. 121-38.

4 The Frida Kahlo Corporation owns the trademark rights and interests to the name Frida Kahlo worldwide <https://fridakahlocorporation.com/> [accessed 18 June 2020]. As to the five hundred peso banknote, it features a self-portrait of Diego Rivera on the reverse alongside a fragment of his painting Desnudo con alcatraces (Nude with Calla Lilies). The motif on the reverse is a self-portrait of Frida Kahlo accompanied by an image of her work El abrazo de amor del Universo, la tierra (México), yo, Diego 


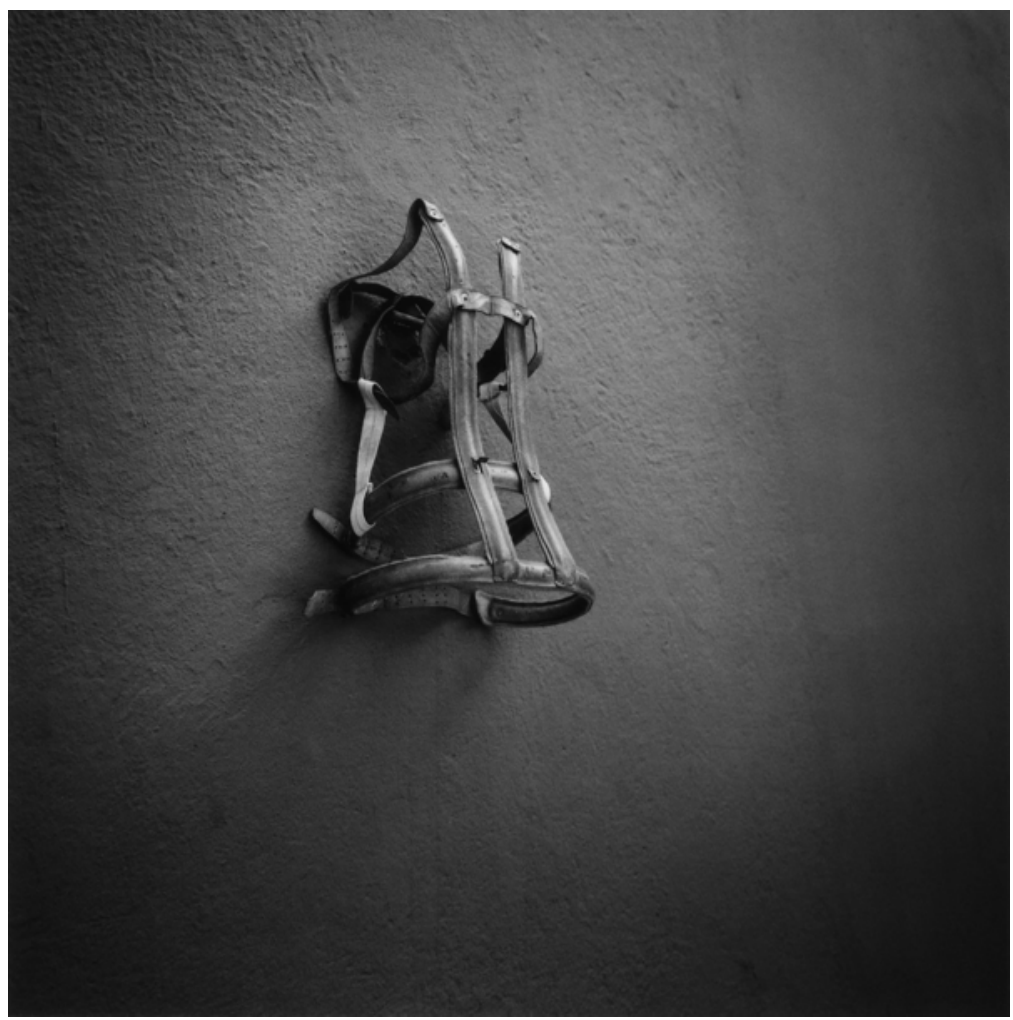

Figure 1. (C) Graciela Iturbide, El baño de Frida viI. Courtesy of the artist.

her personal belongings, including the ones that were found in her bathroom and that allegedly unveil her most guarded secrets, are spectacularly displayed and consumed. ${ }^{5}$

It could be then inferred that Diego Rivera's order to board up her bathroom was intended to protect his wife's intimacy from public view.

y el Señor Xólotl (Love's Embrace of the Universe, Earth (Mexico), I, Diego, and Mr. Xólotl). The banknote will soon be replaced by a new one featuring former Mexican president, Benito Juárez, on the front and a gray whale with its young on the back.

5 The 2018 exhibition, Frida Kahlo: Making Her Self Up, at the Victoria and Albert Museum in London is indicative of this way of presenting Kahlo's legacy: <https: //www.vam.ac.uk/exhibitions/frida-kahlo-making-her-self-up > [accessed 25 May 2020]. For a thoughtful discussion on the 'Fridomanía', see Margo Glantz, 'Frida Kahlo. Diseminación y amplificación’, Revista de la Universidad de México, 104 (2012), pp. 15-25. 
Perhaps, but Iturbide and Bellatin seem to suggest otherwise. Instead of protection, Rivera was seeking exposure, and let weathering do the work. Changes in temperature, humidity, the lack or excess of light, the effects of microorganisms, among other natural agents, subjected the silent dwellers of the bathroom to a series of unpredictable, discrete, and continuous metamorphoses.

Who would have thought that with this intended closure and deferred opening, one of the fathers of Mexican muralism, the archetype of the committed Latin American artist, from the centre of Coyoacán - the centre of the periphery - would be more than two decades ahead of the pop art icon, Andy Warhol, who packed more than three hundred thousand items of his possessions - clothes, bounced checks, toys, letters, acne medicines, nail clippings, a mummified foot, used condoms - into some six hundred sealed cardboard boxes archived with rigorous compulsion during the last thirteen years of his life?

Once closed, Frida's bathroom and Warhol's Time Capsules, become acephalous laboratories of transformation and contingent interactions. Bacteria, humidity, mould, pests - the villains of art preservation - push the artist out of frame. Iturbide photographs the ragged corsets that once supported Frida's body and which now hang in the shower, on a rusted nail, on a coat rack. The hospital gown (are the stains on it paint or blood?) is held by a hanger. Three entangled enema hoses come out of the rusted enamel pots. A stuffed turtle whose shell is falling into pieces rises from the bathtub. Stalin, on a bent poster, sinks into it. The placements of the objects have been sensibly orchestrated and the photographer's attentiveness to the dryness of plastic, the stiffness of leather, the consumed paper and the stained fabric, together with the rather promiscuous arrangements, instead of pointing towards decay and death, infuse a breath of life into the weathered objects that, like the Demerol box, have 'no expiration date'.

Literary critic Paola Cortés-Rocca situates Iturbide's series within the history of still life painting, traditionally relegated to the lowest level in the hierarchy of art genres as it dealt with 'low forms of life' inanimate or non-corporeal objects - and as it took private property as its main subject-matter. ${ }^{6}$ Accordingly, Iturbide's photographs trans-

6 Norman Bryson, Looking at the Overlooked: Four Essays on Still Life Painting (London: Reaktion Books, 1990). 
form the mundane things of Frida's bathroom into aesthetic objects, emphasizing in them the articulation between property, exhibition, and gaze:

This articulation that the still life genre stages - a series of objects are exhibited as someone's property and, in turn, are contemplated as if they could be consumed or appropriated - is transferred to the figure of the artist. In other words: since an institution like the museum is wary of a rusty tin can, an old prosthesis or a worn poster [...], if a series of hoses for making enemas becomes aesthetic material, if they are worthy of occupying the photographic field it is because they once belonged to Frida Kahlo. ${ }^{7}$

But also, these photographs of weathered things locked up in 'the most psychosexually charged room in a building', as Beatriz Colomina and Mark Wigley name it, ${ }^{8}$ might be mapping a cartography of desire that does not conform to the canonical image of the painter. Taking CortésRocca insights one step further, it can be said that Iturbide's disturbing series subtly pay homage to Kahlo's overlooked naturalezas muertas.

Undoubtedly, there has always been a question of life or death at stake in the still life genre, and the ways of naming it in different languages and art traditions account for this tension. Instead of the English term 'still life' (derived from the Dutch stilleven) that connotes immobility but also survival; Romance languages such as French or Spanish adopted, later in time, the term nature morte, which brings immobility closer to death. Aware of this, Kahlo, who spent much of her life in beds, at hospitals and at home, named one of her naturalezas muertas Naturaleza viva (Living Nature or Nature vivante, 1952), and wrote on a slice of watermelon, in her last painting (a still life), Viva la vida (Long Live Life).

Kahlo began painting naturalezas muertas at an early age, the first, Charola de amapolas (Tray with Poppies), dating from 1924. None-

7 Cortés-Rocca, 'La insoportable levedad', p. 128; my translation.

8 In contrast to the generalized disregard that the bathroom has received in architectural thought, Beatriz Colomina and Mark Wigley go as far as to state that 'the history of Modern architecture could be written from the point of view of the toilet'. As an introduction to their original perspective on this topic, see 'Toilet Architecture: An Essay about the Most Psychosexually Charged Room in a Building', PIN-UP Magazine, 23 (Fall/Winter 2017/18), <https://pinupmagazine.org/articles/toiletmodern-architecture/ $>$ [accessed 17 July 2020]. 
theless, as art historian Nancy Deffebach notes, considering the large number of still lifes that Kahlo created over a period of thirty years (more than twenty-five out of a total of one hundred forty-four artworks) few studies have been done on these pieces, which comprise, in addition, many generic transgressions. ${ }^{9}$ According to Deffebach, this omission is probably due to the fact that 'Kahlo's still lifes resist the predominant biographical interpretations that have been applied to her self-portraits. ${ }^{10}$ By the same token, the rare analyses devoted to these works disregard their pictorial specificities and privilege instead popular themes of Kahlo's biography such as her turbulent marriage with Rivera or her physical martyrdom. ${ }^{11}$

However, Kahlo's naturalezas muertas undermine the markers assigned to the artist's public figure: the betrayed wife, the restless rebel, the sufferer. In these works, the protagonists are the transformative affinities between diverse forms of life, as in the weathering process: in Naturaleza muerta (tondo) (Still Life (Round)), for instance, various vegetables and other species, such as mushrooms and flowers, open up to each other like the sliced squash in the middle, a butterfly, and a moth hovering over them; in Naturaleza viva (1952), a pigeon hatches into a sweet potato while some roots write 'Living Nature' on the ground; in Tunas (Prickly Pears, 1938), two half-cut cactus fruits ripe open like an open heart. Iturbide, in her photographical series, echoes the contagious force of these disregarded paintings. She withdraws from the widespread representations of Kahlo and by freeing the artist's objects from a pre-established meaning, she mobilizes new

9 For a detailed analysis of Kahlo's still lifes, see Nancy Deffebach, María Izquierdo and Frida Kahlo: Challenging Visions in Modern Mexican Art (Austin: University of Texas Press, 2015), pp. 135-39.

10 Ibid., p. 135.

11 Deffebach argues that this analytical framework predominates in the works of Helga Prignitz-Poda and Salomon Grimberg. To this respect, she notes: 'Prignitz-Poda literally sees Diego Rivera in the watermelons in Viva la vida (Long Live Life) of 1954 and asserts that in all the slices of melon he "turns around himself as if in a macabre dance of dismemberment", a vision that rather ingeniously facilitates her conclusion that "for Kahlo there is no more room in the world". In a 2004 article titled "Frida Kahlo's Still Lifes”, Salomon Grimberg declares: “Kahlo's still lifes often read like pages in a diary." To illustrate his claim, he alleges that a small piggy bank represents Rivera while a figurine of a horse stands for Kahlo in Still Life with Piggy Bank and Black Horse of ca. 1928. Later in the article he sights Rivera in a slice of watermelon and a prickly pear' (p. 136). 


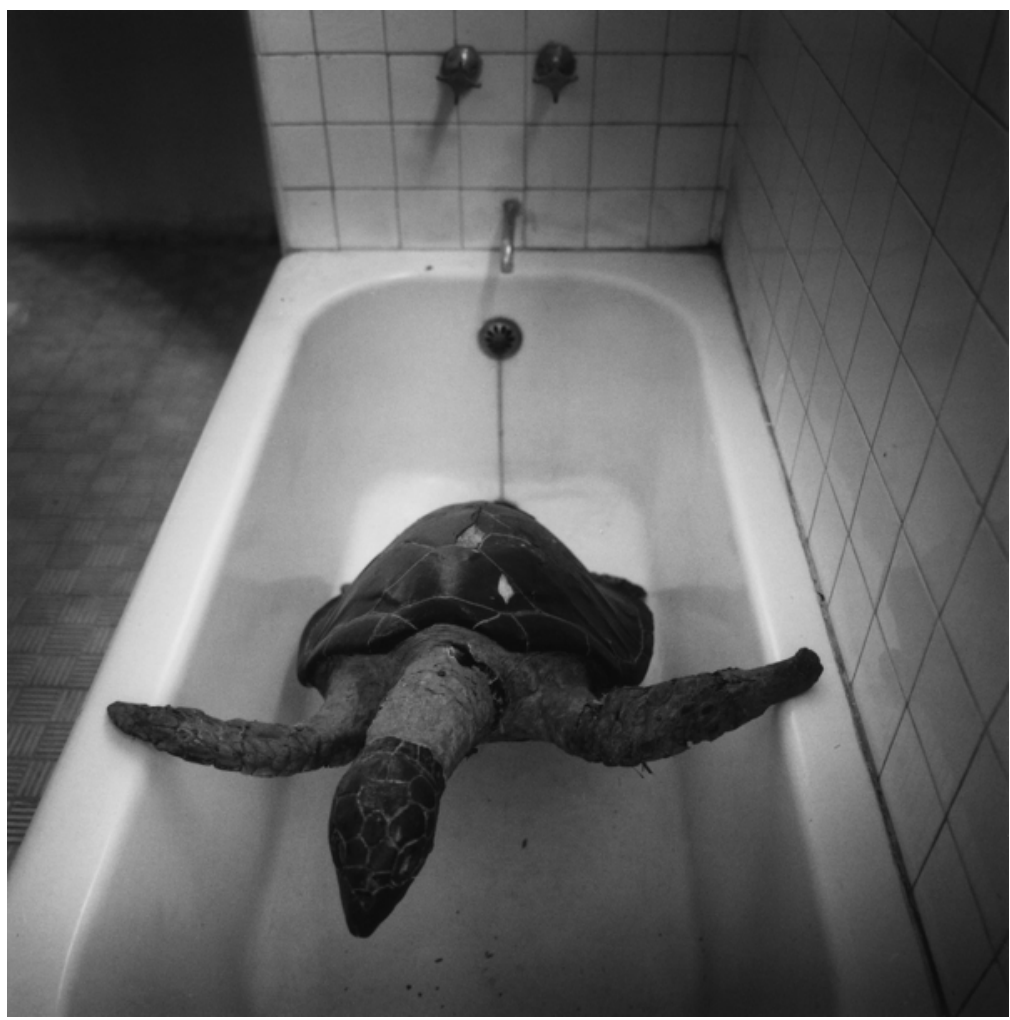

Figure 2. (C) Graciela Iturbide, El baño de Frida XIV. Courtesy of the artist.

lines of interpretation and interrogates the tragic immobility to which Kahlo's oeuvre has been subjected since her death.

At this point, one might suspect a certain archivist drive in The Bathroom of Frida Kahlo, a need to delve into a space where weathering has done its work, and to look for new constellations in what is left. Iturbide acutely reads in the sealed room the construction of a confined weather that would only preserve what matters. Sensitive as he was to the productive architecture of spaces, Rivera decided to make an archival one for Kahlo. He knew, like Warhol, that the archive guarantees the oeuvre's survival, emptying it of its many mystifications, even of the most resistant of all: the authority of the name of the author. 


\section{WEATHERED NAMES}

Demerol without Expiration Date is the second text that Bellatin wrote about Kahlo - the first, which bears the title of one of the painter's most celebrated work, Las dos Fridas, tells the story of a writer who has been commissioned by the Mexican Council for Culture and the Arts (a request officially made to Bellatin) to write Kahlo's biography, and who searches, camera in hand, for a living Frida who is supposed to be working in a Mexican food market.

Las dos Fridas interrogates the mediations between reality and fiction, as well as the causal relationship between a single authorproducer and her corresponding 'original' work. This problem is not new to Bellatin, but rather, it traverses all his texts and artistic interventions. ${ }^{12}$ Demerol without Expiration Date is no exception. In it, Bellatin calls into question the artifices of originality and the figure of the author through another recurrent creative strategy in his writing: the re-utilization of his own texts. Demerol, as we shall see, combines fragments that have already appeared in many of his other books, replicated in such a way that it becomes almost impossible to determine which fragment came first. In this same vein, many of Bellatin's books are advertised as translations of non-existent texts or biographies of fictional characters that are presented as real ones. In other cases, the characters seem to be replicas of Bellatin himself - like the writer of Flores, who uses an orthopaedic leg - or become the authors of Bellatin's books, like frida kahlo who, in Demerol, is virtually alive and has painted three artworks (Damas chinas, Salón de belleza and El jardin de la señora murakami) that are indeed novels published by Bellatin in 1995, 1994, and 2000 respectively:

Once a conference was organized where a teacher introduced himself with a singular didactic apparatus. It was an artefact supplied with a screen, through which a sort of film of reality was shown. [...] Suddenly, the screen began to show images, fragments, of the life of the artist frida kahlo, which was pre-

12 Bellatin is a writer who makes films (such as Bola Negra. Ciudad Juárez's Musical, co-directed with Marcela Rodríguez in 2012), works as a curator (as in dOCUMENTA/13, where he exhibited the project Die hunderttausend Bücher von Bellatin), puts on performances (such as the famous Writers' Doubles Congress in Paris in 2003 and the ongoing Cine vivo). He is also involved in photography and theatre. 


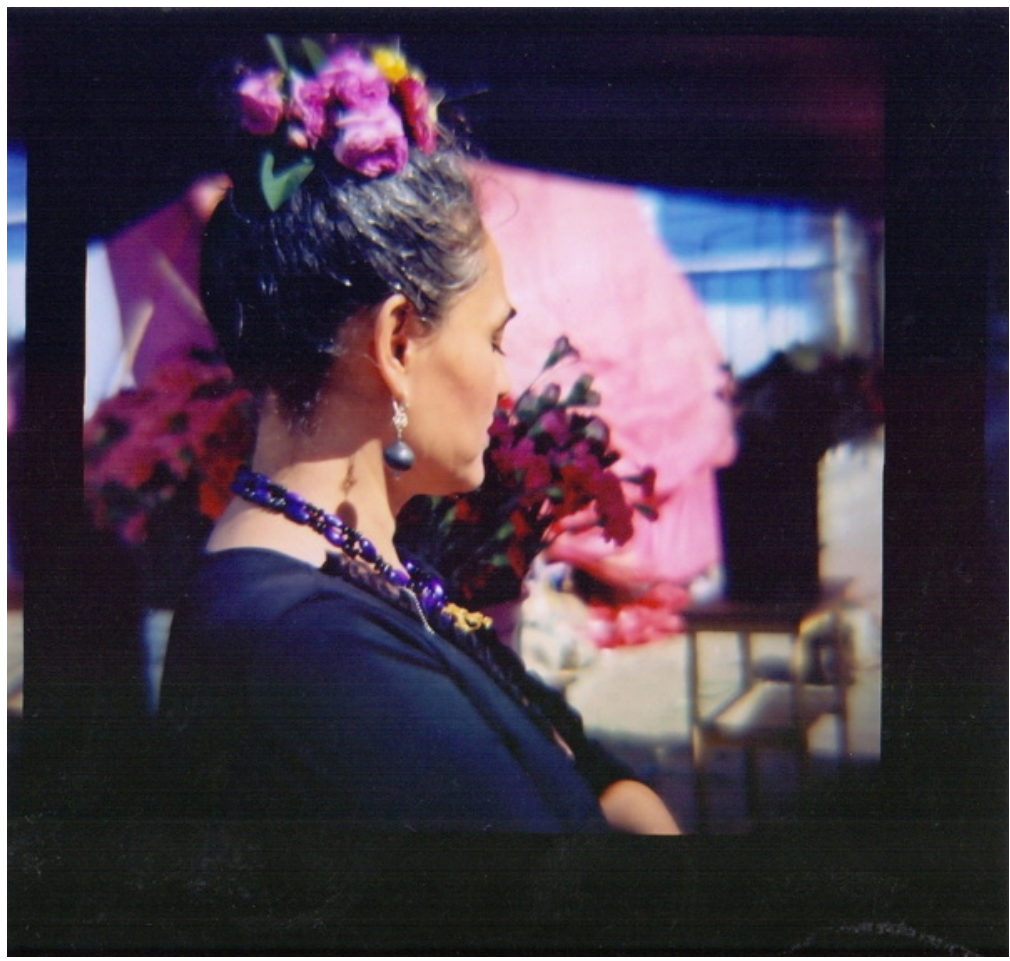

Figure 3. (C) Archivo Mario Bellatin, Las dos Fridas [The Two Fridas]. Image credit: Mario Bellatin.

cisely the theme that had gathered the public that night. The curious thing was that a rather old kahlo was shown, as if she had continued to live after her death. At a certain moment, always through the screen, the image of the Russian leader joseph stalin was seen, placed behind two pewter pots for clysters, and a very old demerol box. The rubber hoses necessary for the enema pots to perform their functions were detached from the receptacles. But the biggest surprise for those present at the conference occurred when three unknown pictorial works were seen through the apparatus. They were entitled Damas chinas, Salón de belleza, and El jardín de la señora murakami. ${ }^{13}$

13 Mario Bellatin, Demerol, sin fech a de caducidad, in Graciela Iturbide and Mario Bellatin, El baño de Frida Kahlo/ Demerol, sin fecha de caducidad (Ciudad de México: Galería López Quiroga/Editorial RM, 2008), p. 2; my translation. 
During the conference, frida shares with the audience her thoughts on the creative process, shows some of her most renowned works and stresses her constant search for 'painting without painting', a phrase that recalls Bellatin's guiding principle 'writing without writing. ${ }^{14}$ Following the pattern of many proper names in Bellatin's work, hers is written in lowercase: frida kahlo. The author becomes a common noun and an empty placeholder to be potentially occupied by any other name. ${ }^{15}$

Bellatin, like Iturbide, always delves into what is left, and what might seem a simple cut-and-paste exercise - the replacement of a proper name by another, the repetitions of chunks of text over which the reader stumbles again and again - is a complex weathering process. For instance, the cited fragment of Demerol also appears in an undated manuscript, probably from the same period. It is named after Malcolm Lowry's famous closing quote from Under the Volcano: 'Do you like this garden that is yours? Don't let your children destroy it.' Bellatin writes:

Once a conference was organized where a teacher introduced himself with a singular didactic apparatus. It was an artefact

14 Paradoxical as it may seem, 'writing without writing' is the way in which Bellatin has labelled his complex creative process, which he succinctly summarizes as follows: 'a constant concern for highlighting the voids, the omissions, rather than the presences'. See Mario Bellatin, 'Escribir sin escribir', in Obra reunida 2 (Barcelona: Alfaguara, 2014), pp. 3-12. For a detailed analysis of Bellatin's writing strategies, see Delfina Cabrera and Graciela Goldchluk, 'Una mortaja de papel: la emergencia del archivo en la escritura de Mario Bellatin', in Bellatin en su proceso: los gestos de una escritura, ed. by Palma Castro, and others (México-Buenos Aires, Benemérita Universidad de Puebla-Prometeo, 2018), pp. 121-46; Juan Pablo Cuartas, Los comienzos de Mario Bellatin: tiempo y consistencia en Efecto invernadero (unpublished thesis, Universidad Nacional de La Plata, Argentina, 2014) <http://www.memoria.fahce. unlp.edu.ar/tesis/te.1044/te.1044.pdf> [accessed 14 April 2020]; Graciela Goldchluk, 'Lecciones de realismo para una liebre muerta (sobre la obra de Mario Bellatin)', I Simposio Internacional Imágenes y Realismos en América Latina, 29 de septiembre al 1 de octubre de 2011, Leiden, Países Bajos, in Actas online, ed. by Miguel Caballero Vázquez, Luz Rodríguez Carranza, and Christina Soto van der Plas <https:// imagenesyrealismosleiden.wordpress.com/ $><$ http://www.memoria.fahce.unlp.edu. ar/trab_eventos/ev.13717/ev.13717.pdf > [accessed 11 June 2020].

15 In Demerol, frida kahlo's paintings carry the titles of Bellatin's novels; she rewrites Kafka's The Metamorphosis and awards samuel beckett the authorship of one of her paintings (La jornada de la mona y el paciente (The Day of the Monkey and the Patient)) which is named after a short story by Bellatin. She also stages a theatre piece based on her painting Beauty Salon, which is the title of Bellatin's most famous novel, published in Lima and later turned into a play in Mexico City. 


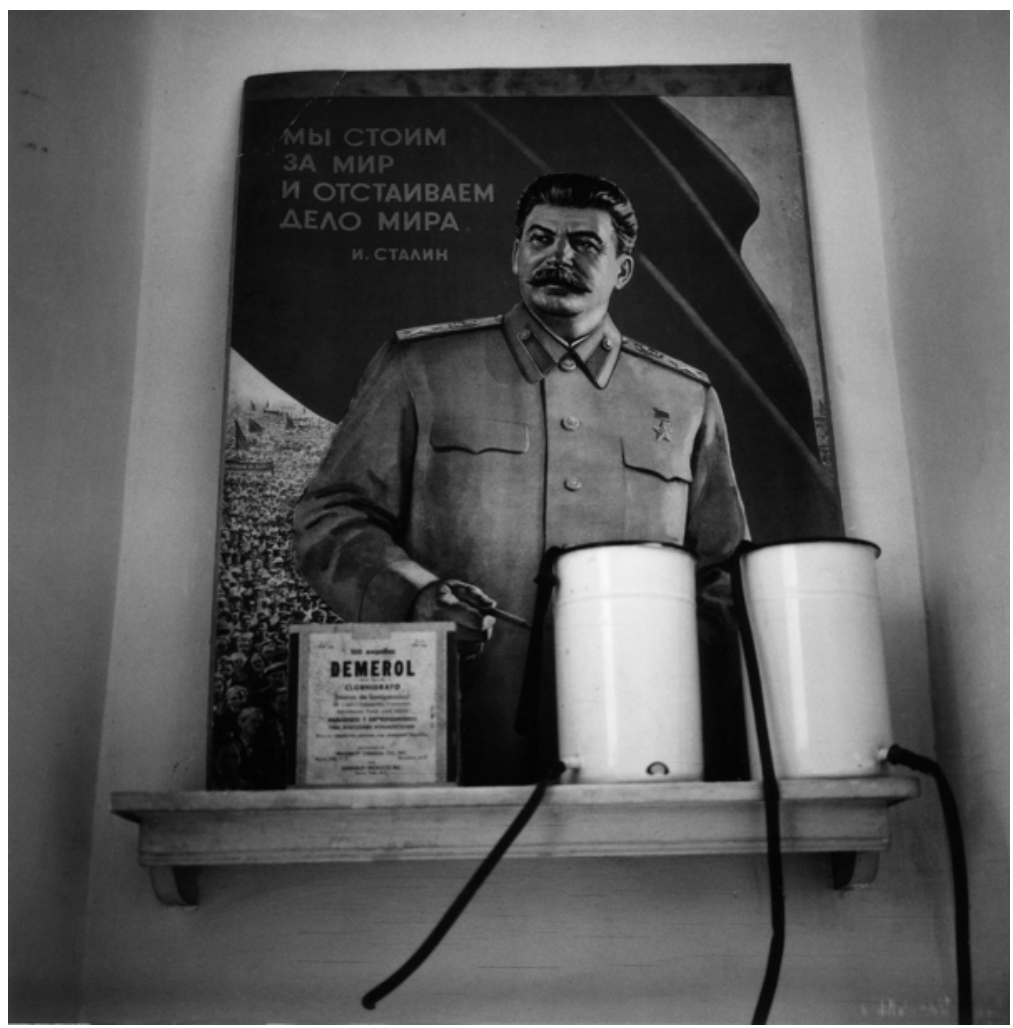

Figure 4. (C) Graciela Iturbide, El baño de Frida XII. Courtesy of the artist.

supplied with a screen, through which a sort of film of reality was shown. [...] Suddenly, the screen began to show images, fragments, of the life of the writer mario bellatin, which was precisely the subject that had gathered the public that night. The curious thing was that a rather old bellatin was shown, as if he had continued to live after his death. At a certain moment, always through the apparatus, the covers of three books were seen: Damas chinas, Salón de belleza and El jardín de la señora murakami. ${ }^{16}$

And again, in Biografía ilustrada de Mishima, a novel almost immediately following Demerol:

16 La Plata, Archivo Mario Bellatin, Universidad Nacional de La Plata, fol. 13; my transcription and translation. 
[Mishima] is now in an educational institution where a lecture will be given on Yukio Mishima. [...] Suddenly a professor who gives the impression of being Japanese appears in the room. Mishima notices that he brings with him an apparatus through which, once installed, he begins to show a sort of film of reality. The attendees stare at the screen. The first image is of the schoolyard where we are gathered. It is a highly prestigious institution. [...] Mishima stays in the room showing a definite sense of superiority. He looks like a middle-aged man. $\mathrm{He}$ wears a military uniform and has no head. ${ }^{17}$

The correspondence of the texts is almost perfect, like a piece of tracing paper that reveals the one underneath, we can spot certain silhouettes that coincide, although this coincidence is never fully achieved. As we compare the fragments, we may think at first glance that they are almost the same, but no: Bellatin's project aims at setting in motion a weathering force capable of eroding any supposed origin or originality of writing. Through overexposure, Bellatin weathers the author's place in order to show the traces, not of a discourse, but of the movements of an improper body in writing, always in progress, errant, incomplete. In this sense, together with the notions of author and oeuvre, what is also challenged in Demerol is the fiction of the normal, organically whole body (even the textual body). Perhaps this explains why, in his more than forty published books, Bellatin has concentrated on creating worlds of his own, confined weathers that only respond to the fiction that sustains them.

\section{CLAUSTROPHILIA}

Since his first novel, Efecto invernadero (Greenhouse Effect), which takes place almost exclusively in one room, Bellatin has locked his characters in places of confinement that are somehow makeshift. Sometimes, one could even say that it is the characters who lock themselves in, perhaps as a counterbalance to the history of confinement of nonnormative bodies: the transvestite hairdresser whose beauty salon, surrounded by aquariums, becomes a moridero (a place to die); the

17 Mario Bellatin, Biografía ilustrada de Mishima (Buenos Aires: Entropía, 2009), p. 4; my translation. 
paralytic dog trainer of Perros héroes (Hero Dogs) who never leaves the house, or the deaf and blind twins locked up in the Colonia de Alienados Etchepare, the madhouse-school-asylum of his most recent book, Carta sobre los ciegos para uso de los que ven (Letter on the Blind for the Use of Those Who Can See). In Demerol, frida is locked into a 'singular didactic apparatus' or, at least, there is no clear indication that her life (her afterlife), can be detached from this machine.

For this reason, even if in Demerol, there are rather few direct references to Frida's bathroom (only the hoses for making enemas, the orthopaedic leg and Stalin's poster are mentioned in some passages), the text revolves around an atmospheric problem in its most basic sense: how is life possible in a closed space? Such a problem also intrigued Roland Barthes, who references it in his famous 1977 lecture series How to Live Together, which explores the tension between the individual and the common through several confined spaces, such as the monastery, the bourgeois house, the hotel room, or the desert. ${ }^{18}$ Indeed, Barthes considers the desert to be the archetype of a closed space, precisely because it appears to be an open space, but one from which it is impossible to escape and which denotes, etymologically, extreme solitude (from the Greek eremos and from the Latin eremus: desert, solitary).

Hence, it is no coincidence that this space becomes the landscape of the last performance of frida in Demerol: while preparing an artistic presentation for a congress on cinema and mysticism to which she had been invited, frida recalled the column prop of Luis Buñuel's film Simon of the Desert: ${ }^{19}$

frida remembered that someone had told her that the column of buñuel's film - a film she had not been able to appreciate in life - was abandoned in the desert. kahlo then set about the task of getting a recent image of the column. As one might imagine, she was not in a position to go personally to the place where the column was, but she asked for a picture of it. Finally, a perfect image arrived. [...] frida kahlo, after admiring it for a few days, had it framed as if it were a religious image. She

18 Roland Barthes, How to Live Together: Novelistic Simulations of Some Everyday Spaces, trans. by Kate Briggs (New York: Columbia University Press, 2012).

19 Simón del desierto, dir. by Luis Buñuel (Sindicato de Trabajadores de la Producción Cinematográfica, 1965). 
also made a series of saint cards of the column and distributed them among her neighbours. The next day she photographed them one by one holding the saint cards. kahlo pretended that her neighbours were members of a brotherhood that had been created around the lost column. The text that accompanied the photos mentioned that a group of people had decided to flee the city in order to improve their living conditions. On the way to their pilgrimage they found the column from bunuel's film. These people decided to take this astonishing event as a sign and settled in the column's surroundings. ${ }^{20}$

Bellatin carried out a similar performance himself, using a picture that had been taken by Graciela Iturbide:

I remembered that someone had told me that in the pachuca desert there was still the column from which Luis Buñuel had made his film Simon of the Desert. [...] Simon of the Desert is one of my favourite films and it perfectly fits into the category of cinema and mysticism. In the research I undertook, I found that the photographer Graciela Iturbide had images of the column that she herself had taken. I asked her to give me one as a present and had it framed as a religious picture. I printed out a series of those framed images and I distributed them among my neighbours. [...] Then, I photographed the people to whom I had given the images to pass them off as members of a brotherhood that had been created from the forgotten column. ${ }^{21}$

In the desert, the 'realm of weathering' par excellence, Demerol goes back to The Bathroom of Frida Kahlo. The survival of works of art, Bellatin and Iturbide suggest, depends not only on its display but on its opening up to a commons. Contrary to the logics of the museum, their archival operations contest aseptic protocols. Theirs is an invitation to a living archive that welcomes time and weather, and shelters what can be shared: 'Another tenant lives now in your house', such is the final line of Simon of the Desert. The devil's daughter speaks it to the son of God. In the column, writes Mario Bellatin, thousands of tenants now live.

20 Mario Bellatin, Demerol, p. 14.

21 Mario Bellatin, 'Escribir sin escribir', in Mario Bellatin, Obra reunida 2 (Barcelona: Alfaguara, 2014), p. 11. 


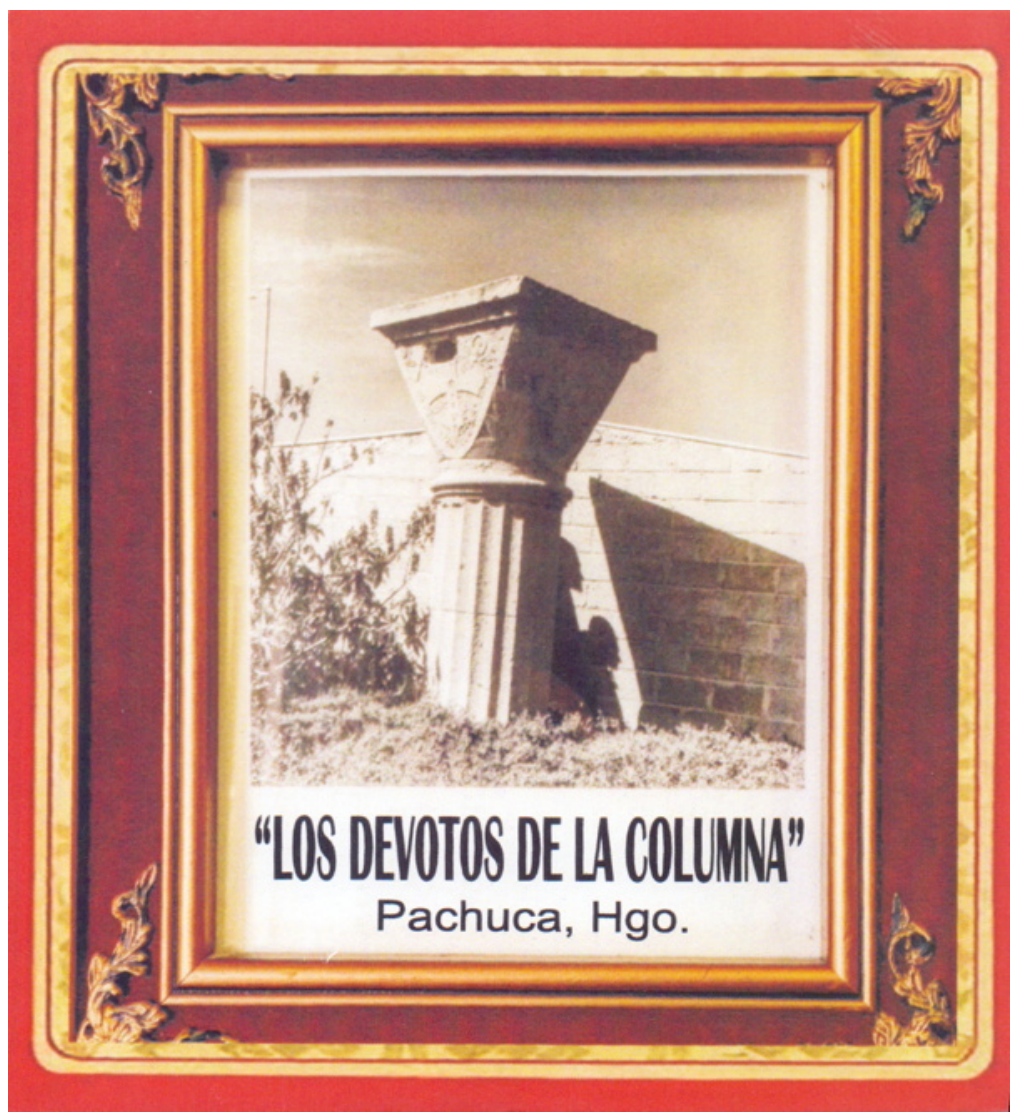

Figure 5. (C) Archivo Mario Bellatin, Los devotos de la columna [The Devotees of the Column]. Image credit: Mario Bellatin. 
Delfina Cabrera, 'Confined Weathers: Graciela Iturbide and Mario Bellatin's The Bathroom of Frida Kahlo/Demerol without Expiration Date', in Weathering: Ecologies of Exposure, ed. by Christoph F. E. Holzhey and Arnd Wedemeyer, Cultural Inquiry, 17 (Berlin: ICI Berlin Press, 2020), pp. 295-309 < https: //doi.org/10.37050/ci-17_15>

\section{REFERENCES}

\section{BIBLIOGRAPHY}

Barthes, Roland, How to Live Together. Novelistic Simulations of Some Everyday Spaces (New York: Columbia University Press, 2012)

Bellatin, Mario, Biografía ilustrada de Mishima (Buenos Aires: Entropía, 2009)

- Carta sobre los ciegos para uso de los que ven (Madrid: Alfaguara, 2017)

L Las dos Fridas (Ciudad de México: Conaculta, 2008)

- Efecto invernadero (Ciudad de México: Ediciones del Equilibrista, 1992)

_ ¿Le gusta este jardín que es suyo? No deje que sus hijos lo destruyan' (Archivo Mario Bellatin: Universidad Nacional de La Plata), fol. 13

- Obra reunida 2 (Barcelona: Alfaguara, 2014)

- Salón de belleza (Lima: Jaime Campodónico Editor, 1994)

Bryson, Norman, Looking at the Overlooked: Four Essays on Still Life Painting (London: Reaktion Books, 1990)

Cabrera, Delfina, and Graciela Goldchluk, 'Una mortaja de papel: la emergencia del archivo en la escritura de Mario Bellatin', in Bellatin en su proceso: los gestos de una escritura, ed. by Palma Castro, and others (México-Buenos Aires: Benemérita Universidad de Puebla-Prometeo, 2018), pp. 121-46

Colomina, Beatriz, and Mark Wigley, 'Toilet Architecture: An Essay about the Most Psychosexually Charged Room in a Building', PIN-UP Magazine, 23 (Fall/Winter 2017/18) <https://pinupmagazine.org/articles/toilet-modern-architecture/> [accessed 17 July 2020]

Cortés-Rocca, Paola, 'La insoportable levedad del yo. Iturbide y Bellatin en el baño de Frida Kahlo', Filología, 41 (2012), pp. 121-38

Cuartas, Juan Pablo, Los comienzos de Mario Bellatin: tiempo y consistencia en Efecto invernadero (unpublished thesis, Universidad Nacional de La Plata, Argentina, 2014) <http: //www.memoria.fahce.unlp.edu.ar/tesis/te.1044/te.1044.pdf $>$ [accessed 14 April 2020]

Deffebach, Nancy, María Izquierdo and Frida Kahlo: Challenging Visions in Modern Mexican Art (Austin: University of Texas Press, 2015)

Glantz, Margo, 'Frida Kahlo. Diseminación y amplificación', Revista de la Universidad de México, 104 (2012), pp. 15-25 
Goldchluk, Graciela, 'Lecciones de realismo para una liebre muerta (sobre la obra de Mario Bellatin)', I Simposio Internacional Imágenes y Realismos en América Latina, 29 de septiembre al 1 de octubre de 2011, Leiden, Países Bajos, in Actas online, ed. by Miguel Caballero Vázquez, Luz Rodríguez Carranza, and Christina Soto van der Plas <https://imagenesyrealismosleiden.wordpress.com/> <http://www.memoria.fahce.unlp.edu.ar/trab_eventos/ev.13717/ev.13717.pdf> [accessed 11 June 2020]

Iturbide, Graciela, and Mario Bellatin, El baño de Frida Kahlo/Demerol, sin fecha de caducidad (Ciudad de México: Galería López Quiroga/Editorial RM, 2008)

Schettini, Ariel, 'En el castillo de Barbazul. El caso Mario Bellatin', Otra Parte, 6 (Winter 2005), pp. 14-17

\section{FILMOGRAPHY}

Simón del desierto, dir. by Luis Buñuel (Sindicato de Trabajadores de la Producción Cinematográfica, 1965) 